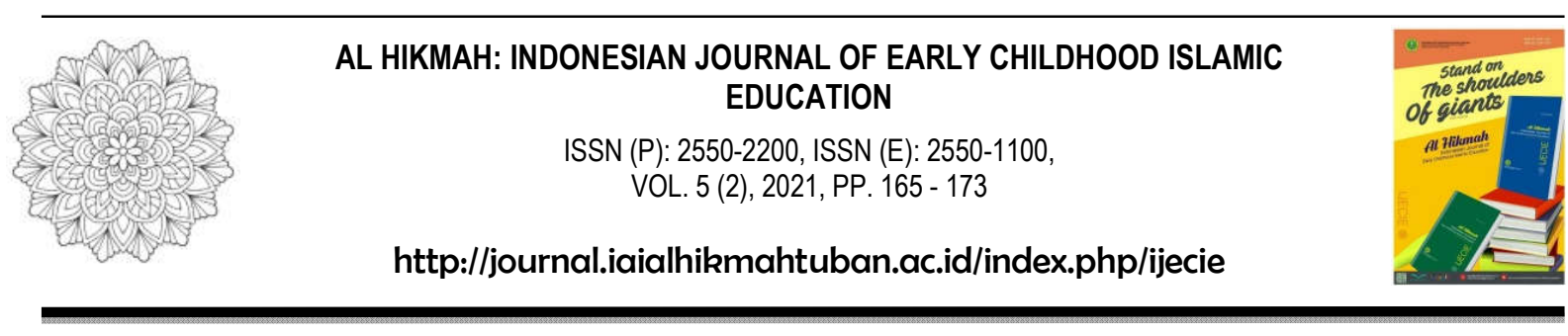

\title{
STRATEGI MANAJEMEN KONFLIK PENDIDIKAN AUD DI MASA PANDEMI
}

\author{
Rusdiana Navlia ${ }^{1}$, Danang Prastyo ${ }^{2}$, Azhar Amrullah Hafizh ${ }^{3}$, Sofia Mubarokah Sa'bana ${ }^{4}$ \\ 12 PIAUD, Tarbiyah, Institut Agama Islam Negeri Madura \\ ${ }^{3}$ IQT, Ushuluddin dan Dakwah, Institut Agama Islam Negeri Madura \\ ${ }^{4} \mathrm{HKI}$, Syariah, Institut Agama Islam Negeri Madura \\ rusdianannavlia005@gmail.com
}

\begin{abstract}
Abstrak
Dalam mencerdaskan kehidupan bangsa kebijakan pemerintah Indonesia di sector pendidikan yang mendukung pendidikan seanjang hayat adalah diakuinya pendidikan anak usia dini .Konflik merupakan sesuatu yang tidak dapat dihindarkan dalam kehidupan. Dalam interaksi dan interalisasi social antar individu atau antar kelompok. Konflik sebenarnya merupakan hal alamiah, bahkan sepanjang kehidupan manusia senantiasa dihadapkan dan bergelut dengan konflik. Dahulu konflik danggap sebagai gejala atau fenomena yang tidak wajar dan berakbat negative maunpun positif tergantung bagaimana cara mengelolanya.Saat ini banyak dari sebagian orang tua yang mungkin masih salah memahami tentang devinisi dan tujuan dari pendidikan anak usia dini. Hal ini memenag bisa di maklumi mengingat fungsi pendidikan anak usia dini di beberapa kota atau daerah, pendidikan anak usia dini yang sebenarnya adalah lembaga pendidikan untuk mengembangkan karakter dan kepribadian anak lebih sering dipahami sebagai tempat penitipan anak.
\end{abstract}

Kata Kunci: Manajemen Konflik, Pendidikan AUD, Pandemi

\section{Abstract}

In educating the nation's life, the Indonesian government's policy in the education sector that supports lifelong education is the recognition of early childhood education. Conflict is something that cannot be avoided in life. In social interaction and internalization between individuals or between groups. Conflict is actually a natural thing, even as long as human life is always faced and struggles with conflict. In the past, conflict was seen as a symptom or phenomenon that was unnatural and had negative or positive consequences depending on how to manage it. Currently, many parents may still misunderstand the definition and purpose of early childhood education. This is understandable considering the function of early childhood education in several cities or regions, early childhood education which is actually an educational institution to develop the character and personality of children is more often understood as a place of day care.

Keywords: Conflict Management, AUD Education, Pandemic 
PENDAHULUAN

World Health Organization (Badan Kesehatan Dunia) atau yang lebih dikenal dengan singkatan WHO mulai tanggal 09 Maret 2020 telah secara resmi mendeklarasikan bahwa virus corona (Covid-19) merupakan pandemi yang harus diantisipasi dan ditanggulangi bersama penyelasaiannya. Hal ini juga mengakibatkan beberapa sektor mengalami keguncangan dan pergeseran peran, salah satunya dalam sektor pendidikan. Sekolah yang merupakan tempat belajar, kini mulai bergeser pada pembelajaran daring yang lebih banyak dilakukan dari rumah. Hal ini merupakan salah satu upaya pemerintah dalam mencegah penyebaran virus covid-19 dengan mengeluarkan kebijakan agar setiap sekolah melakukan pembelajaran di rumah melalui sistem pembelajaran daring. Kembali pada pengertiannya, bahwa sistem pembelajaran daring merupakan sistem pembelajaran tanpa tatap muka secara langsung antara pendidik dengan peserta didik, melainkan menggunakan media online dengan jaringan internet atau yang lebih dikenal dengan singkatan daring.

Pembelajaran daring atau dalam jaringan merupakan kegiatan pembelajaran yang memanfaatkan jaringan internet (menggunakan LAN maupun WAN) sebagai metode penyampaian, interaksi dan fasilitas pembelajaran dengan didukung oleh berbagai bentuk layanan belajar lainnya. Hal ini dapat dirasakan manfaatnya terhadap kegiatan pembelajaran di kelas yang menggunakan system pembelajaran jarak jauh (distance learning) ragam manfaat pelaksanaannya yaitu sebagai: Suplemen, Komplemen dan Subtitusi.

Terdapat beragam macam pola pembelajaran daring yang menjadi pilihan. Pilihan pertama, yaitu hampir 99,9\%-100\% para guru disekitar penulis yang menggunakan fasilitas WhatsApps atau sering dikenal dengan singkatan WA, dalam hal ini, guru membuat WhatsApps group sehingga semua siswa dapat terlibat aktif di dalamnya. Macam-macam tugas juga diberikan melalui aplikasi ini. Bahkan jika dalam pembelajaran ada siswa yang masih belum memahami keterangan atau materi yang diberikan, maka guru akan menambahkan dengan mengirimkan video ataupun melakukan WhatsApps Video Call dengan siswa. Penggumpulan tugaspun dilakukan melalui WhatsApps. Bahkan melalui aplikasi ini para guru bukan hanya membagi materi pembelajaran dengan bentuk teks, namun juga dalam bentuk video tutorial dan power point. Selanjutnya siswa mengunduh materi tersebut dan mempelajarinya. Disaat penulis berdialog dengan salah satu guru, beliau mengemukakan bahwa penggunaan WA karena dinilai lebih ekonomis, lebih praktis dan hemat biaya. Adapun proses penilaian yang dilakukan oleh para guru yaitu dengan menambahkan menambahkan tugas dalam bentuk Google-Form. 
Rusdiana Navlia, dkk (Strategi Manajemen Konflik)

Adapun pola pembelajaran yang menjadi pilihan kedua, yaitu aplikasi pendukung WhatsApps, yaitu dengan menggunakan aplikasi Zoom, Google-Classroom, Google-Drive maupun Google-Form. Penggunaan Google-Form digunakan dalam pengumpulan tugas akhir sekaligus untuk evaluasi tingkat pemahaman siswa. Tambahan yang lainnya adalah aplikasi Youtube, yaitu dengan mengunggah video agar dapat ditonton oleh siswa, dengan durasi yang telah disesuaikan dengan materi.

Terdapat beberapa kelebihan dan kekurangan di dalam penerapannya, Kelebihan pertama dalam pembelajaran daring adalah lebih parktis dan santai, hal ini dirasa praktis karena dapat memberikan tugas setiap saat dan pelaporan tugas setiap saat. Kedua, lebih fleksibel bisa dilakukan kapanpun dan dimanapun. Pembelajaran daring menyebabkan waktu yang lebih fleksibel bagi wali yang bekerja di luar rumah dan bisa menyesuaikan waktu untuk mendampingi siswa belajar. Ketiga, hemat waktu dan dapat dilakukan kapan saja. Semua siswa dapat mengaksesnya dengan mudah, artinya dapat dilakukan dimana saja. Penyampaian informasi lebih cepat dan bisa menjangkau banyak siswa lewat WA Group. Keempat, disamping praktis juga memudahkan dalam pengambilan nilai pengetahuan terutama bila memakai Google Form. Jika menggunakan Google Form, nilai bisa langsung diketahui, hal tersebut dapat membuat siswa lebih tertarik dalam mengerjakan tugas. Selain itu siswa juga dimudahkan dalam pengerjaannya. Siswa tinggal memilih pilihan jawaban yang dianggap benar dengan meng-klik pilihan jawaban yang dimaksud. Kelebihan kelima adalah adanya pemantauan dan pendampingan dari para orang tua dikarenakan pembelajaran daring ini lebih banyak dilakukan di rumah. Kelebihan keenam, guru dan siswa memperoleh pengalaman baru terkait pembelajaran daring dan hal penting dari pembelajaran ini dapat langsung terasa yaitu adanya peran orang tua dalam mendampingi anak/siswa yang lebih intens dari biasanya.

Adapun Kelemahan dalam Pembelajaran Daring menurut penulis, selama pembelajaran daring berlangsung seringkali pembelajaran ini dirasa kurang maksimalnya akibat dari kurangnya keterlibatan aktif dari para siswa. Keterlibatan siswa yang dimaksud dapat dilihat dari hasil keterlibatan siswa dalam mengikuti pembelajaran daring secara penuh dari awal pembelajaran sampai akhir pembelajaran. Dari hasil pengamatan menunjukkan bahwa hamper $60-80 \%$ siswa yang aktif terlibat secara penuh di dalam pembelajaran, 15-20 $\%$ siswa yang terlibat setengah aktif. Sedangkan 5-15\% terdapat siswa kurang aktif atau kurang berpartisipasi dalam pembelajaran daring dengan beragam alasan. Namun yang menjadi persoalan adalah bagaimana pola pembelajaran daring ini dapat berjalan baik bagi siswa anak usia dini, yang dimana pada masa ini anak-anak membutuhkan waktu 
Rusdiana Navlia, dkk (Strategi Manajemen Konflik)

pendampingan lebih banyak dari pada mereka yang sudah memasuki jenjang Pendidikan formal di tingkat sekolah dasar hingga menengah atas.

\section{METODE}

Metode pengumpulan data pada penelitian ini menggunakan konsep studi empiric dengan sifat deskriptif analisis. Menurut Nazir (1988), metode deskriptif merupakan suatu metode dalam meneliti status sekelompok manusia, suatu objek, suatu set kondisi, suatu sistem pemikiran ataupun suatu kelas peristiwa pada masa sekarang. Tujuan dari penelitian deskriptif ini adalah untuk membuat deskripsi, gambaran, atau lukisan secara sistematis, faktual dan akurat mengenai fakta-fakta, sifat-sifat serta hubungan antarfenomena yang diselidiki. Sedangkan menurut Sugiyono (2005) menyatakan bahwa metode deskriptif adalah suatu metode yang digunakan untuk menggambarkan atau menganalisis suatu hasil penelitian tetapi tidak digunakan untuk membuat kesimpulan yang lebih luas. Menurut Whitney (1960), metode deskriptif adalah pencarian fakta dengan interpretasi yang tepat.

Metode penelitian dengan pendekatan kualitatif-deskriptif digunakan sebagai teknik analisis data yang dilakukan secara bertahap. Masalah yang dapat diteliti dan diselidiki oleh penelitian kualitatif deskriptif ini mengacu pada studi kuantitatif, studi komparatif, serta dapat menjadi sebuah studi korelasi antara satu unsur dengan unsur lainnya. Kegiatan penelitian ini meliputi pengumpulan data, analisis data, interprestasi data, merumuskan suatu kesimpulan dan diakhiri dengan memberikan solusi praktis sesuai dengan data dan perkembangan teknologi.

\section{HASIL DAN PEMBAHASAN}

Pendidikan anak usia dini merupakan jenjang pendidikan yang ditempuh anak sebelum ia masuk ke sekolah dasar (SD). Pendidikan anak usia dini adalah suatu pembinaan yang diperuntukan bagi anak 0-6 tahun,dimana usia ini menjadi usia emas pembembentukan kepribadian dan karakter anak. Sayangnya,banyak orang tua yang salah memahami tujuan pendidikan anak usia dini sebagai lembaga pendidikan .

Saat ini banyak dari sebagian orang tua yang mungkin masih salah memahami tentang devinisi dan tujuan dari pendidikan anak usia dini. Hal ini memenag bisa di maklumi mengingat fungsi pendidikan anak usia dini di beberapa kota atau daerah . pendidikan anak usia dini yang sebenarnya adalah lembaga pendidikan untuk mengembangkan karakter dan kepribadian anak lebih sering dipahami sebagai tempat penitipan anak. 
Penddikan anak usia dini merupakan salah satu bentuk penyelenggaraan pendidikan yang menitikberatkan pada peletakan dasar kearah pertumbuhan dan enam perkembangan diantaranya agama dan moral,fisik motoric, kognitif, bahasa, social emosional, dan seni,sesuai dengan keunikan dan tahap tahap perkembangan sesuai kelompok usia yang dilalui oleh anak usia dini .

\section{Konflik Pada Pendidikan Anak Usia Dini}

Menjalani kegiatan dirumah atau isolasi atau juga bisa disebut dengan karantiana mandiri selama maasa pandemic virus corona mungkin telah terasa sangat menjemukan bagi setiap orang tetapi akan lebih menjenuhkan yang dialamai oleh anak anak usia 4-5 tahun (anak usia dini). Bagi anak anak bermain dengan teman dpaat mengusir kejenuhan dan pembelajaran, hal itu tentunya perlu didapat diluar rumah. perasaan terkurung dan pertanyaan kapan semua ini akan bisa menjadi pemicu stress saat pandemic virus corona pada saat ini. Adapun problem yang muncul pada anak usia dini akibat stay at home yaitu :

a. Stress pada anak

b. Banyak tugas belajar yang harus dikerjkan oleh anak

c. Orang tua tiak sabar dalam menemani anak dalam belajar

d. Manja atau tidak mandiri

e. Sulit untuk dinasehati

f. Anak tidak bisa belajar dengan baik

\section{Penyebab Terjadinya Konflik}

Suatu organsasi hampir dapat di pastikan akan menghadapi konflik, baik bersifat eksternal maupun internal, dan dapat bersifat positif maupun negative. Konflik merupakan suatu proses dimana suatu pihak merasa bahwa pihak lain telah atau akan mengambil tindakan yang bertentangan dengan kepentingan pihak lain. Suatu interaksi dapat menimbulkan terjadinya konflik di antara mereka yang berinteraksi, antara lain sebagai berikut:

\section{Perceptual Distortin (penyimpangan persepsi)}

Orang cenderung biasa dalam melihat seseorang atau sesuatu. pada umunya kita cenderung melihat situasi dengan cara menguntungkan kita sendiri. Hal tersebut karena terjadi distori dala persepsi kita sehingga menjadi tidak objektif dalam memandang sesuatu. 
2. Grudges (Dendam)

Seringkali konflik disebabkan karena orang takut kehilangan muka dalam berhubungan dengan orang lain dan berusaha berbuat sama dengan orng tersebut dengan merencanakan bentuk pembalasan.

3. Distrust (ketidakpercayaan)

Semakin kuat orang menyangka bahwa apabila individu atau kelompok meninggalkan mereka, maka hubungan antara orang dan kelompk tersebut diliputi oleh konflik. Renggangnya hubungan antara orang atau kelompok disebabkan oleh perasaan bahwa pihak lainnya tidak dapat dipercayai.

Penyebab konflik ada bermacam-macam. Beberapa sebab yang penting adalah sebagai berkut :

1. Saling bergantungan. Saling bergantung dalam pekerjaan terjadi jika dua kelompok organisasi atau lebih saling membutuhkan satu sama lain guna menyelesaikan tugas.

2. Perbedaan tujuan. Perbedaan tujuan yang ada diantara satu bagian dengan bagian yang lain, seperti unit produksi yang bertujuan semaksimal mungkin biaya produksi mengusahakan sedikit mungkin kerusakan produk.

3. Perbedaan persepsi. Dalam menghadapi suatu masalah jka terjadi perbedaan persepsi maka hal itu dapat menyebabkan munculnya konflik.

4. Kesibukan orang tua. Dalam beberapa keluarga dijumpai anak mengalami kesulitan belajar akibat dari para orang tua yang lebih mementingkan karir dari pada memberi pendampingan aktif terhadap putra-putrinya.

\section{Strategi Mengtasi Konflik Pendidikan AUD di Masa Pandemi}

Langkah meraih ketenangan dalam koflik pendidikan dapat diselesaikan dengan 5 langkah, yaitu sebaga berikut:

1. Pengenalan

Kesenjangan antara keadaan yang ada diidentifkasi dan bagaimana keadaan yang seharusnya. Salah satunya yang menjadi perangkap adalah kesalahan dalam mendeteksi.

2. Diagnosis

Inilah langkah yang penting. Metode yang benar dan telah diuji mengenai siapa saja, apa mengapa, dimana dan bagaimana berhasil dengan sempurna.

3. Menyepakati suatu solusi

Kumpulkan masukan yang mengenai jalan keluar yang memungkinkan dari orangorang yang terlibat didalamnya. 
4. Pelaksanaan

Ingatlah bahwa akan selalu ada keuntungan dan kerugian. Hati- hati jangan biarkan pertimbangan ini terlalu mempengaruhi pilihan dan arah kelompok.

5. Evaluasi

Penyelesaian itu sendiri dapat melahirkan serangkaian masalah baru jika penyelesaiannya tampak tidak berhasi, kembalilah ke langkah sebelunya dan cobalah lagi.

Anak merupakan generasi bangsa yang perlu dijaga tumbuh kembangnya, sehingga kita semua harus bisa menghilangkan ego diri untuk mengasah keterampilan, keahliaan dalam pengembangan media pendidikan dan kunci utama untuk solusi dari segala masalah tersebut yaitu kemampuan untuk merasakan kebutuhan anak, karena dengan cara ini kita dapat meluangkan waktu, tenaga dan uang demi ketercapaian tujuan Pendidikan anak. Disamping beberapa hal yang telah tertulis diatas, terdapat 3 tehnik penanggulangan konflik yang juga dapat kita terapkan dalam pola Pendidikan dan pembelajaran daring khususnya bagi anak AUD, hal ini bertujuan agar kegiatan belajar dapat tetap berjalan sesuai tujuan Pendidikan walaupun berlangsung dari rumah. Tiga tehnik ini bisa disingkat dengan Model pendidikan 3M, yaitu Mengkondisikan, Mengaktifkan dan Melakukan Umpan Balik Pembelajaran, berikut kami jelaskan cara penerapannya:

1. Proses mengkondisiskan, yaitu dengan mengajak anak untuk belajar dengan metode yang telah dirancang oleh orang tua atau guru. Dalam pembelajaran daring, maka orang tua ataupun guru perlu melakukan penjelajan pada anak terkait bagaimana cara/tutorial penggunaan aplikasi dan penerapannya dalam pembelajaran.

2. Proses mengaktifkan, ialah sebuah usaha/cara untuk membangun proses belajar yang lebih aktif, yaitu dengan pemilihan model tugas belajar yang menyenangkan bukan bersifat banyak dan membosankan. Misalnya dalam tugas daring, anak diminta untuk memperlihatkan hasil kerjanya dan menjelaskannya secara daring di depan temantemannya, hal ini dapat mewujudkan rasa senang anak dalam belajar karena adanya interaksi aktif secara live antara orang tua, guru dan murid di ruang virtual.

3. Proses melakukan umpan balik, umpan balik merupakan proses akhir yang tidak boleh dilupakan. Misalnya dalam pembelajaran daring, guru dapat melakukan umpan balik dengan mengevaluasi secara langsung hasil kerja siswa dan melakukan penilaian, hal ini juga dapat disertai dengan pemberian reward and punishment. 


\section{PENUTUP}

\section{Simpulan}

Konflik merupakan sesuatu yang tidak dapat dihindarkan dalam kehidupan. Dalam interaksi dan interalisasi social antar individu atau antar kelompok. Konflik sebenarnya merupakan hal alamiah, bahkan sepanjang kehidupan manusia senantiasa dihadapkan dan bergelut dengan konflik. Dahulu konflik danggap sebagai gejala atau fenomena yang tidak wajar dan berakbat negative maunpun positif tergantung bagaimana cara mengelolanya.

Penddikan anak usia dini merupakan salah satu bentuk penyelenggaraan pendidikan yang menitikberatkan pada peletakan dasar kearah pertumbuhan dan enam perkembangan diantaranya agama dan moral, fisik motorik, kognitif, bahasa, social emosional, dan seni,sesuai dengan keunikan dan tahap tahap perkembangan sesuai kelompok usia yang dilalui oleh anak usia dini.

Adapun problem yang muncul pada anak usia dini akibat stay at home yaitu: Stress pada anak, Banyak tugas belajar yang harus dikerjkan oleh anak, Orang tua tiak sabar dalam menemani anak dalam belajar, manja atau tidak mandiri, dan Sebagian dari anak tidak bisa belajar dengan baik karena kesibukan orang tua. Maka dalam hal ini peran serta orang tua menjadi hal yang penting, utamanya dalam mensukseskan pendidikan dan pengajaran walau dilaksanakan secara daring akibat pandemic covid 19. Disini para orang tua dapat menerapkan model pendidikan 3M, yaitu Mengkondisikan, Mengaktifkan dan Melakukan Umpan Balik Pembelajaran

\section{Saran}

Artikel ini merupakan gambaran ringan yang memunculkan beberapa konflik yang sering terjadi, khususnya yang dialami oleh beberapa siswa dan para orang tua serta guru selama proses Pendidikan dan Pengajaran yang terjadi di tengah pandemic covid 19 yang tak kunjung mereda. Dalam artikel ini pula penulis memberikan sedikit langkah alternatif yang mungkin dapat dijadikan sebagai langkah solutif dalam mengatasi konflik serta ragam problem di dalam proses Pendidikan dan Pengajaran tersebut. Namun, beberapa tehnik menejemen konflik yang telah penulis paparkan masih jauh dari kesempurnaan, layaknya sebuah sistem yang masih jauh dari kesempurnaan, sangat diperlukan tambahan dan penyempurnaan ide serta gagasan dari para pemerhati Pendidikan lainnya guna mengelola hambatan dan mensukseskan Pendidikan Bersama khususnya bagi Pendidikan anak di usia dini. 


\section{DAFTAR PUSTAKA}

Ana Widyastuti dkk. (2020). Manajemen konflik berbasis sekolah. Medan: Yayasan Kita Menulis.

Hayes, (2003). Panduan memahami dan mengatasi ledakan emosi pada anak. Jakarta: Erlangga.

Fitriyani, (2007). Manajemen konflik; definisi, sumber, dampak dan strategi. Jakarta: Raja grafindo persada.

Nazir, M. (1988). Metodologi Penelitian. Jakarta: Ghalia Indonesia.

Parapat, Asmidar. (2020). Strategi Pembelajaran Anak Usia Dini. Tasikmalaya: Edu Publisher.

Puspita, Weni. (2018). Manajemen Konflik (Suatu Pendekatan Psikologi, Komunikasi, dan Pendidikan). Sleman: Deepublish.

Rachmawati, Yeni. (2012). Strategi Pengembnagan Kreativitas Pada Anak Usia Taman Kanak-Kanak. Jakarta: Kencana.

(2010). Strategi pengembangan kreaaativitas pada anak usia dini. Jakarta: Kencana.

Watson, R., McKenna, H., Cowman, S., \& Keady, K. (Eds.). (2008). Nursing research: Designs and methods. Edinburgh, Scotland: Churchill Livingstone Elsevier.

Winardi, (2004). Manajemen perilaku organisasi. Jakarta: kencana. 